\title{
Test Stand Dynamics Properties Investigation by Means of Simulation Computations
}

Lenka Valčáková, Veronika Štefaňaková

University of Žilina, Faculty of Mechanical Engineering, Department of Transport and Handling Machines, Univerzitná 1, 01026 Žilina, e-mail: lenka.valcakova@fstroj.uniza.sk, veronika.stefanakova@fstroj.uniza.sk

The paper is devoted to the mechanical system dynamic properties investigation of the test stand RAILBCOT (RAIL vehicles Brake Components Test stand). Using sensors attached to some parts, have been measured values of positions, the longitudinal, vertical and transversal forces, revolutions and accelerations. There was created computational model of the mechanical system in SIMPACK software system environment. There were performed model establishment, starting and boundary condition setting and simulation computations to determine the dynamic properties parameters. The measured values were compared with calculated values. Subsequent verification has been confirmed the necessity of modification of the flexible member of the bench. The paper consists of issue definition and the comprehensive references specification from the field of investigation of working team at the University of Žilina relevant to this field of study.

Keywords: test bench, multibody system dynamics, RAILBCOT, SIMPACK, simulation computations

\section{Acknowledgement}

The work was supported by the Scientific Grant Agency of the Ministry of Education of the Slovak Republic and the Slovak Academy of Sciences in project No. 1/0347/12: "Railway wheel tread profile wear research under the rail vehicle in operation conditions simulation on the test bench", project No. 1/0383/12: "The rail vehicle running properties research with the help of a computer simulation." and the project No. APVV-0842-11: "Equivalent railway operation load simulator on the roller rig".

\section{Research-Educational Center of Rail Vehicles (VVCKV)}

\section{References}

[1] GERLICI, J., LACK, T., HARUŠINEC, J., MÜLLER, R., DOLEŽEL, P. (2011). Rail vehicles brake components test stand. (In Slovak). In: PRORAIL 2011: Žilina, 21.-23.9.2011, conference proceedings. - Žilina: Scientific and Technical Society at the University of Žilina, 2011. ISBN 978-80-89276-30-1, (pp. 233-241).

[2] GERLICI, J., LACK, T., HARUŠINEC, J. (2012). RAILBCOT - Rail vehicles brake components test stand (In Slovak). Computational and experimental methods in applied mechanics. - Ústí nad Labem: Faculty of production technologies and management University J. E. Purkyně, 2012). ISBN 978-80-7414-377-9, (pp. 165-172).

[3] GERLICI, J., LACK, T., HARUŠINEC, J. (2012). RAILBCOT - the rail vehicles brake components test stand (In Slovak). In: Computational and experimental methods in applied mechanics. - Ústí nad Labem: UJEP, 2012. ISBN 978-80-7414-377-9, (pp. 165-172).

[4] GERLICI, J., LACK, T., HARUŠINEC, J. (2014). Development of test stand prototype for rail vehicles brake components testing. In: Communications: scientific letters of the University of Žilina. - ISSN 1335-4205. - Vol. 16, no. 3A (2014), (pp. 27-32).

[5] GERLICI, J., LACK, T. (2014). Rail vehicles brake components test bench utilisation In: Applied mechanics and materials. ISSN 1660-9336. Vol. 486 (2014), online ISSN 1662-7482, (pp. 379-386). Trans Tech Publications, Switzerland.

[6] GERLICI, J., LACK, T., HARUŠINEC, J. (2014). Rail vehicles wheels and brake blocks wear laboratory test stand utilization. In: Prace Naukowe. Transport: Analiza i ocena elementów systemów transportowych. ISSN 1230-9265. - Z. 101 (2014), (pp. 21-32).

[7] SUCHÁNEK, A., HARUŠINEC, J., GERLICI, J., LACK, T. (2013). Test stand for railway whels wear investigation function parts modification. (In Slovak). In: Computational and experimental methods in applied mechanics I. - Ústí nad Labem: Faculty of production technologies and management UJEP, 2013. ISBN 978-80-7414-609-1, (pp. 151-158).

[8] GERLICI J., LACK T., HARUŠINEC J. (2013). SIMRAIL - the load modulus of the test stand for the realistic simulation of railway operation in laboratory conditions. In: Dynamics of flexible and rigid bodies 2013: proceedings of the XI. International scientific conference, Ústí nad Labem, 9.-11.10 2013. FVTM UJEP, 2013. ISBN 978-80-7414-607-7. - CD-ROM, (p.8). 
[9] GERLICI J., LACK T., HARUŠINEC J., (2013): The test stand load modulus implementation for the realistic railway operation in the laboratory conditions. Paper number: M2013183. Manufacturing technology. Vol. 13, Nr.4., ISSN 1213-2489. Journal for science, research and production. December 2013. Issued by J.E. Purkyně University in Ústí nad Labem, Faculty of Production Technology and Management, (pp. 444 -449).

[10] ŠTEFAŇAKOVÁ V., GERLICI J., LACK T., HARUŠINEC J. (2013). Test stand load modulus construction proposal for the realistic simulation of railway operation. In: TRANSCOM 2013: 10th European conference of young researchers and scientists : Žilina, June 24. - 26. 2013, Slovak Republic. - Žilina: University of Žilina, 2013. ISBN 978-80-554-0695-4, (pp. 305-308).

[11] ŠTEFAŇAKOVÁ V. (2013). Test stand loading modul for realistic simulation of rail vehicle operation (In Slovak). In: Experimental and computational method in engineering: Conference proceedings. 11. - 13. 6. 2014, Ústí nad Labem, Czech Republic. - Ústí nad Labem: Univerzita J. E. Purkyně], 2014. ISBN 978-80-7414-725-8. - CDROM, (p.10).

[12] HARUŠINEC, J., GERLICI, J., LACK, T., ŠTEFAŇAKOVÁ, V. (2014). Angle of attack setting on the test stand system concept modification (In Slovak). In: Dynamics of flexible and rigid bodies 2014: Proceedings of the XII international scientific conference: Ústí nad Labem, 8.-10.10 2014. FVTM UJEP, 2014. ISBN 978-80-7414-7494. - CD-ROM, (p. 16).

[13] GERLICI, J., LACK, T. (2008). Modified HHT Method Usage for Vehicle Vibration Analysis in Time Domain. In: Communications - scientific letters of the University of Žilina. ISSN 1335-4205, 2/2008, (pp. 26-32).

[14] GERLICI, J. - LACK, T. (2014). Modified HHT method for vehicle vibration analysis in time domain utilisation. In: Applied Mechanics and Materials. ISSN 1660-9336. Vol. 486 (2014), online ISSN 1662-7482, (pp. 396- 405). Trans Tech Publications, Switzerland

[15] LACK, T., GERLICI, J. (2007). The Programme System DELTA Exploitation for Numerical Analysis Performances, (in Slovak). In: 18-th. International Conference “Current Problems in Rail Vehicles - PRORAIL 2007” Proceedings of lectures, Part II. pp. 11-22, EDIS, ISBN 978-80- 89276-07-3, Zilina 2007.

[16] SOUKUP, J., VALEŠ, F., VOLEK, J. SKOČILAS, J. Transient vibration of thin viscoelastic orthotropic plates. Acta Mechanica Sinica, vol. 27, no 1, p. 98-107. The Chinese Society of Theoretical and Applied Mechanics; Institute of Mechanics, Chinese Academy of Sciences, co-published with Springer, ISSN 0567-7718 (Print), 16143116 (online).

[17] SKOČILAS, J., SKOČILASOVÁ, B., SOUKUP, J. Determination of the rheological properties of thin plate under transient vibration. Latin American Journal of Solids and Structures. Brasil society for mechanics and engineering. ISSN 1679-7817 (print), 1679-7825 (online).

[18] SVOBODA, M., SKOČILAS, J., SOUKUP, J. (2011). Analysis of vertical vibration of mechanical system. In: Dynamical systems. Analytical /Numerical Methods, Stability, Bifurcation and Chaos". (pp. 261 - 268). Department of Automation and Biomechanics. Polytechnika Lodž., 2011

[19] SVOBODA, M., SOUKUP, J. (2013) Verification of numeric solution by experiment for examination vertical oscillation of a mechanical system. In: Manufacturing Technology. ISSN 1213-2489, 2013, vol. 13, iss. 4, (pp. 559-563).

[20] GERLICI, J., LACK, T. (2003): Rail geometry analysis (from the point of view of wearing in the operation). In: Communications - scientific letters of the University of Žilina. ISSN 1335-4205. - Vol. 5, No. 1 (2003), (pp. 4351).

[21] GERLICI, J., LACK, T. (2005). Wheelset/rail geometric characteristics assessment with regard to wheelset rolling. In: Communications - scientific letters of the University of Žilina. ISSN 1335-4205. - Vol. 7, No. 1 (2005), (pp. 5$10)$.

[22] GERLICI, J., LACK, T., LACKOVÁ, M. (2004). Calculation of the equivalent conicity function of the railway wheelset tread profile at the Delta $\mathrm{R}$ function with a negative slope. In: Communications - scientific letters of the University of Žilina. ISSN 1335-4205. - Vol. 6, Nr. 2 (2004), (pp. 49-56).

[23] GERLICI, J., LACK, T. et all. (2005). Transport means properties analysis: Volume 1 (2005) - 1st ed. - Žilina: University of Žilina, 2005. (214 p.), ISBN 80-8070-408-2.

[24] GERLICI, J., LACK, T. (2010). Contact geometry influence on the rail / wheel surface stress distribution. In: Procedia Engineering. ISSN 1877-7058. - Iss. 1 (2010), (pp. 2249-2257).

[25] LACK, T., GERLICI, J. (2005). Contact area and normal stress determination on railway wheel / rail contact. In: Communications - scientific letters of the University of Žilina. ISSN 1335-4205. - Roč. 7, č. 2 (2005), (pp. 38-45). 
[26] LACK, T., GERLICI, J. (2012). Wheel / rail contact stress evaluation by means of the modified strip method utilization. In: VSDIA 2012: proceedings of the 13th mini conference on Vehicle system dynamics, identification and anomalies: 5-7 November, 2012 Budapest, Hungary. - [S.1.: s.n.], 2012. - ISBN 978-963-313-102-2, (pp. 261269).

[27] LACK, T., GERLICI, J. (2012). Modified Strip Method utilisation for wheel /rail contact stress evaluation In: 9th international conference on contact mechanics and wear of rail/ wheel systems (CM2012): 27.-30. August 2012, Chengdu, China: proceedings. Chengdu: Southwest Jiaotong University, (pp. 87-89).

[28] LACK, T., GERLICI, J. (2013). Wheel/rail contact stress evaluation by means of the modified Strip method. In: Communications: scientific letters of the University of Žilina. ISSN 1335-4205. - Vol. 15, no. 3 (2013), (pp. 126132).

[29] LACK, T., GERLICI, J. (2013). The FASTSIM method modification in speed up the calculation of tangential contact stresses between wheel and rail. In: Manufacturing technology: journal for science, research and production. ISSN 1213-2489. - Vol. 13, no. 4 (2013), (pp. 486-492).

[30] LACK, T., GERLICI, J. (2014). A modified strip method to speed up the calculation of normal stress between wheel and rail. In: Applied mechanics and materials. ISSN 1660-9336. Vol. 486 (2014), online ISSN 1662-7482, (pp. 359-370).

[31] LACK, T., GERLICI, J. (2014). A modified strip method to speed up the tangential stress between wheel and rail calculation. In: Applied mechanics and materials. ISSN 1660-9336. Vol. 486 (2014), online ISSN 1662-7482, (pp. 371-378). Trans Tech Publications, Switzerland

[32] LACK, T., GERLICI, J. (2014) Wheel/rail tangential contact stress evaluation by means of the modified strip method. In: Communications: scientific letters of the University of Žilina. ISSN 1335-4205. - Vol. 16, no. 3A (2014), (pp. 33-39).

[33] GERLICI, J., LACK, T. (2011). Railway wheel and rail head profiles development based on the geometric characteristics shapes. In: Wear: an international journal on the science and technology of friction, lubrication and wear. ISSN 0043-1648. - Vol. 271, No. 1-2 Sp. iss. (2011), (pp. 246-258).

[34] SKOČILAS, J., SKOČILASOVÁ, B., SOUKUP, J. (2012). Mechanical model of a vehicle - eigenfrequencies determination (in Czech). In: Calculation and experimental methods in applied mechanics (in Czech) (pp. 201208), FVTM UJEP in Ústí nad Labem 2012, ISBN 978-80-7414-377-9.

[35] SOUKUP, J., VOLEK, J. et al. (2008). Mechanical systems vibration - vehicles. Non-symmetry influence analysis (in Czech). Acta Universitatis UJEP Ústí nad Labem, (269 p), ISBN 978-80- 7414-020-4.

[36] POLACH, P., HAJŽMAN, M., SOUKUP, J., VOLEK, J. (2009). Analytical and numerical investigation of trolleybus vertical dynamics on an artificial test track. Applied and Computational Mechanics, Vol. 3, No. 2, pp. 351362, (2009), University of West Bohemia Plzen̆, Czech Republic, ISSN 1802-680X.

[37] SOUKUP, J., VOLEK, J. et al. (2008). Mechanical systems vibration - vehicles. Non-symmetry influence analysis (in Czech). Acta Universitatis UJEP Ústí nad Labem, (269 p). ISBN 978-80- 7414-020-4.

[38] NANGOLO, F.,N., SOUKUP, J., SVOBODA, M. (2012). Modelling of vertical dynamic response of railway vehicle system with experimental validation. In: Machine Modelling and Simulation, (pp. 295- 302), Politechnika Poznaňska, Rokosovo, 2012, Pland, ISBN 978-83-923315-2-0.

[39] DIŽO, J., GERLICI, J., LACK, T. (2013). The goods wagon equipped by Y25 bogies computer simulation analysis. In: TRANSCOM 2013: 10-th European conference of young researchers and scientists: Žilina, June 24-26, 2013, Slovak Republic. University of Žilina, 2013. ISBN 978-80-554-0695-4, (pp. 63-66).

[40] SVOBODA, M., SOUKUP, J. (2013). Dynamic measurement of four-axle railway wagon. In: Manufacturing Technology. ISSN 1213-2489, 2013, vol. 13, iss. 4, (pp. 552-558).

[41] DIŽO, J. (2015). Evaluation of ride comfort for passengers by means of computer simulation. Manufacturing technology. February 2015, Vol. 15, No.1. ISSN 1213-2489, (pp.8-14).

[42] GERLICI J., LACK T. (2003). Test benches computer control software tools development. In: Scientific bulletin of North University of Baia Mare: Fascicle: Mechanics, Tribology. Technology of Machine Manufacturing. ISSN 1224-3264. - Series C, Vol. XVII (2003), (pp. 181-186).

[43] GERLICI, T., LACK, T., HARUŠINEC, J. (2012). Test stand properties analysis for wheel-tread wear in accordance with the laboratory simulated railway operation. In: VSDIA 2012: proceedings of the 13th mini conference on Vehicle system dynamics, identification and anomalies: 5-7 November, 2012 Budapest, Hungary. - [S.1.: s.n.], 2012. - ISBN 978-963-313-102-2, (pp. 157-165). 
[44] VALČÁKOVÁ, L., LACK, T., GERLICI, J., HARUŠINEC, J. (2013). Rail vehicles brake components test stand dynamic properties evaluation. In: TRANSCOM 2013: 10-th European conference of young researchers and scientists: Žilina, June 24-26, 2013, Slovak Republic. - Žilina: University of Žilina, 2013. - ISBN 978-80-554-0695-4, (pp. 321-324).

[45] GERLICI, J., LACK, T., HARUŠINEC, J. (2013). Wheels tread wear stand analysis in accordance to the laboratory simulated railway operation. In: Dynamical problems in rail vehicles 2013: Slovak - Polish scientific workshop: Žilina June 24th and 25th, 2013 Slovak Republic. Žilina: University of Žilina, Department of Transport and Handling Machines. ISBN 978-80-554-0841-5, (pp. 40-55).

[46] GERLICI, J., LACK, T., DOLEŽEL, P., HARUŠINEC, J. (2014). Test stand mechanical system dynamics analysis. In: Prace Naukowe. Transport: Analiza i ocena elementów systemów transportowych. ISSN 1230-9265. - Z. 101 (2014), (pp. 7-20).

[47] VALČAKOVÁ, L. (2014). Dynamics analysis methods of mechanical system of the test stand. (In Slovak). In: Experimental and computational methods in engineering [CD ROM]: conference proceedings [Ústí nad Labem : Univerzita J. E. Purkyně], 2014. ISBN 978-80-7414-725-8. (p.8)

[48] GERLICI, J., LACK, T., HARUŠINEC, J. (2014). Realistic simulation of railway operation on the RAILBCOT test stand. In: Applied mechanics and materials. ISSN 1660-9336. Vol. 486 (2014), online ISSN 1662-7482, (pp. 387-395). Trans Tech Publications, Switzerland.

[49] LACK, T., GERLICI, J., VALČÁKOVÁ, L. (2014). Test stand dynamics properties research by means of simulation computations. (In Slovak). In: Dynamics in rigid and deformable bodies 2014: proceedings from the XII. International scientific conference: Ústí nad Labem, 8.-10.10.2014. - Ústí nad Labem: FVTM UJEP, 2014. - ISBN 978-80-7414-749-4. - CD-ROM, (p. 13). 